\title{
Unnatural London: The Metaphor and The Marvelous in China Mieville's Perdido Street Station
}

\begin{abstract}
Alexandre Veloso de Abreu*
Abstract

This paper explores allegorical and unnatural elements in China Miéville's novel Perdido Street Station, starting with a parallel between the fictional city New Crobuzon and London. Fantasy literature examines human nature by means of myth and archetype and science fiction exploits the same aspects, although emphasizing technological possibilities. Horror is said to explore human nature plunging into our deepest fears. We encounter the three elements profusely in the narrative, making it a dense fictional exercise. In postclassical narratology, unnatural narratives are understood as mimetical exercises questioning verisimilitude in the level of the story and of discourse. When considered unnatural, narratives have a broader scope, sometimes even transcending this mimetical limitation. Fantastical and marvelous elements generally strike us as bizarre and question the standards that govern the real world around us. Although Fantasy worlds do also mirror the world we live in, they allow us the opportunity to confront the model when physically or logically impossible characters or scenes enhance the reader's imagination. Elements of the fantastic and the marvelous relate to metaphor as a figure of speech and can help us explore characters' archetypical functions, relating these allegorical symbols to the polis. In Miéville's narrative, such characters will be paralleled to inhabitants of London in different temporal and spatial contexts, enhancing how the novel metaphorically represents the city as an elaborate narrative strategy.
\end{abstract}

Keywords: Fantastic. Novel. China Miéville. Perdido Street Station.

\section{Londres não-natural: metáfora e o maravilhoso no romance Estação Perdido da China Mieville}

\begin{abstract}
Resumo
Este artigo explora elementos alegóricos e não naturais no romance Perdido Street Station (Estação Perdido), de China Miéville, começando com um paralelo entre a cidade fictícia New Crobuzon e Londres. A literatura de fantasia examina a natureza humana por meio do mito e do arquétipo e a ficção científica explora os mesmos aspectos, embora enfatizando as possibilidades tecnológicas. O horror explora a natureza humana mergulhando em nossos medos mais profundos. Encontramos os três elementos profusamente na narrativa, tornando-a um denso exercício ficcional. Na narratologia pós-clássica, as narrativas não naturais são entendidas como exercícios miméticos questionando a verossimilhança no nível da história e do discurso. Quando consideradas antinaturais, as narrativas têm um escopo mais amplo, às vezes até transcendendo essa limitação mimética. Elementos fantásticos e maravilhosos geralmente nos parecem bizarros e questionam os padrões que governam o mundo real ao nosso redor. Embora os mundos de fantasia também espelhem o mundo em que vivemos, eles nos permitem a oportunidade de confrontar o modelo quando personagens ou cenas fisicamente ou logicamente impossíveis realçam a imaginação do leitor. Elementos do fantástico e do maravilhoso se relacionam com a metáfora como uma figura de linguagem e podem nos ajudar a explorar as funções arquetípicas dos personagens, relacionando esses símbolos alegóricos à polis. Na narrativa de Miéville, esses personagens serão comparados aos habitantes de Londres em diferentes contextos temporais e espaciais, realçando como o romance representa metaforicamente a cidade como uma estratégia narrativa elaborada.
\end{abstract}

Palavras-chave: Fantástico. Romance. China Miéville. Perdido Street Station.

Recebido: 27/09/2018 Aceito: $31 / 10 / 2018$

\footnotetext{
* Pontifícia Universidade Católica de Minas Gerais (PUC Minas). Professor no Programa de Pós-graduação em Letras da PUC Minas.
} 
Fantasy literature elaborates on human nature by means of myth and archetype and science fiction exploits the same aspects, although emphasizing technological possibilities. Horror is said to explore human nature plunging into our deepest fears. We encounter the three elements profusely in China Miéville's novel Perdido Street Station, recognizing the novel as a dense fictional exercise.

Fantastic elements alternate with scientific ones and horror is mainly present through the grotesque, represented by bizarre hybrid characters. What makes this all possible is the somewhat discernible idealization of the swelling and dissolute New Crobuzon, city of steam agglomerates and blurred emulsified atmospheres. Together with Miéville's beautifully wrought language, the creation of this city is the high point of the novel. He elaborates a vision of hell to unbalance imagination. The seductive melody of the prose paradoxically creates dissonance in the netherworld atmosphere of the urbe.

Unlike most cities in fantasy fiction, which are generally idealized as a setting, New Crobuzon is a presence as profound and expressive as any of the characters of the novel. Miéville deprives the reader from considerable amounts of contextualization, but such strategy works as an advantage of making the city more intense. Few details of the polis will appear, reminding an in medias res introduction, most of the spaces remain unexplored by the narrator. Extensive references will be made to history and mythology but won't be elaborated on.

New Crobuzon is immediately associated with London, especially Victorian London, meant to be a mutated and deviant version of the city. The grimy Victorian cesspool can be seen at the dockland where amphibian stevedores and worm-hauled ships lay, an allusion to the east of Tower Bridge in the late nineteenth century.

Looking at a New Crobuzon map we see vast similarities between the two cities. London has the Thames cleaving it but in a more chaotic display, though. New Crobuzon reminds us of encephalic mass roughly circular with uneven edges. The rivers Tar and Canker meet in order to form the Gross Tar deep within the city. We can say New Crobuzon is a fantastic, steampunk, oneiric version of London. Miéville's re-fashioned secondary London becomes the main character of Perdido Street Station, with the continual modification of its inhabitants' perceptions of the constantly changing aspects of the city.

New Crobuzon is, fundamentally, a hybrid city. Everything and everyone fused somehow. Humans, animals, and machines are intermingled and reformed into a mixture that is constantly changing. Such aspect is also an allusion to London. Such hybridity can also be seen in the modifiers used in the narrative. "Complexitude" for instance, is a lexical creation, a hybrid of the words "complexity" and "multitude". Complexitude as a hybrid word made specifically for the city, because it concisely describes New Crobuzon's nature, a very accurate depiction of the alienated individuals, social groups, and species. The hybridity of the city is somewhat mesmerizing and at the same time terrible sight, and it is not always something that makes its citizens comfortable. It is interesting to notice that one form of punishment in New Crobuzon is to be "remade". The punished citizen is surgically altered, often with the addition of prosthetics or mechanics. In a way their identity is remodeled for some subservient purpose.

Though a parliamentary city-state, New Crobuzon's government seems more like an oligarchy having strong imperialistic convictions. The "Fat Sun" party rules most of the time, but shares the parliamentary ambience with the xenophobic "Three Quills" and the xenotolerant "Diverse Tendency". The system is biased towards the human majority and exerts oppressive adjudication towards other species. Such conflicts may also be seen as an allusion to the city of London and to the political system of the United Kingdom.

Spatial perceptiveness is a relevant issue here. For New Crobuzon is interpreted in many ways by its inhabitants. Canadian geographer Edward Relph focusses his studies in spatial perception 
and considers space and place as dialectically structured in human environmental experience. The understanding of space is related to the places human beings inhabit and eventually gains meaning from their spatial context. Therefore, the nature of place and its significance are directly related to the dimension of human life and experience. Relph begins his acclaimed Place and Placelessness elaborating on space and its relationship to place. "Space is much more than a simple container that capsules places or a mere isometric plane that organizes constructions."(cf. SEAMON, 2008) Instead, space can only be really perceived if related to a more experientially-based understanding of place. Space must be explored in terms of how people experience it as well, only then it will really signify something. This will enhance allegorical aspects suggested in the narrative and we can see how vastly it is exploited.

Mieville is laboriously descriptive, especially with the city edifications. The narrative depicts an obscure and oppressive tone of the architecture. The environs are portrayed inhibiting the inhabitants, mainly the huge central train station that entitles the novel. It imposes scary magnificence, together with The Crow, the rail hub and central government building of New Crobuzon. This massive construction figures in the centre of the city where all sky rails and land rails terminate. The Crow is where the ambassadorial suites are located. Only the Spire, the main Militia building of the city, is taller.

In the Eastern Suburbs we have the chthonic edification known as The Ribs, which consists of fossilized bones of a long forgotten behemoth that spontaneously burst from the soil and took over the landscape. They could only afford building around it, for the structure was thicker than trees and harder than stone.

The Ribs rose from the earth at the edges of the empty ground.
Leviathan shards of yellowing ivory thicker than the oldest trees exploded out of the ground, bursting
away from each other, sweeping up in a curved ascent until, more than a hundred feet above the
earth, looming now over the roofs of the surrounding houses, they curled sharply back towards each
other. They climbed as high again till their points nearly touched, vast crooked fingers, a god-sized
ivory mantrap.
There had been plans to fill the square, to build offices and houses in the ancient chest cavity, but
they had come to nothing.
Tools used on the site broke easily and went missing. Cement would not set. Something baleful in
the half-exhumed bones kept the gravesite free of permanent disturbance. (MIÉVILLE, 2000, p. 29)

Here we can see a paradox of the primitive and the modern, since the city surrounded the bone structure and grew to encompass it. Modern edifications could not supplant the fossil, to some extent; technology cannot deal with the primitive or magic.

The Glasshouse is where the Cactacae live. Acity within New Crobuzon, with its own characteristics. A colossal ingot and fibre dome that covers diverse city blocks. The temperature inside the place located in Riverskin is arid as a desert and only Cactacae bear living inside, although an occasional visitor can be spotted. Again, allegorical aspects call our attention.

Allegory is known to be an element of figurative language that produces the virtualization of meaning, transmitting one or more senses beyond what is said to be the literal comprehension of something. In its etymological origin "alegoria" (greek allós = other; agourein = speech) refers to the action of saying one thing signifying another. Ancient rhetoric constitutes allegory as such phenomenon, theorizing it as a modality of utterance, therefore, a discursive ornament. Lausberg explores the resource in Aristotle, Cicero, and Quintilian and defines allegory as a continuing metaphor of the trope of human thought, allowing it to be constantly changing. The Greek verb állegorein can either signify 'speak allegorically' or 'interpret allegorically'. Allegory can be understood as an interpretation technique that helps decipher what words represent. The Greek word simbolus means something that unites. Allegories tend to symbolic representations, which convey literal sense to a representation, making allegory a sophisticated type of metaphor. 
To understand the complexity of the metaphor as a narrative strategy, I recur to Paul Ricoeur's acclaimed The Rule of Metaphor in order to analyze the resourcefulness of the figure of speech.

Ricoeur sees metaphor in three distinct levels. First, he analyzes it in the works of Aristotle, mainly Poetics, to study the figure of speech in its lexis, a "word level". Secondly, the structuralist linguist Émile Benveniste is contemplated to illustrate the metaphor in its phrasal level. Ricouer concludes his study by presenting the metaphor in a discourse level, its most complex and complete manifestation.

According to Ricoeur, Aristotle considers metaphor as a transposition of a name to another name via analogy. Within metaphor we face the intricate concepts of displacement, extension, and substitution of the name. The major goal of this strategy would be persuasion, mainly in oral discourse and in tragic poetry. The philosopher understands that Language has infinite resources that enhance discourse in creative ways. The elaboration of metaphors and creation of narratives are genuine ways of vivid discourse confection.

The major debate in The Rule of Metaphor centers itself "in the linguistic productive imagination that generates and regenerates meaning through the power of metaphoricity to state things in new ways." (Dauenhauer \& Pellauer, 2011, p. 06). Ricoeur points out that new metaphors, ones that weren't reduced to commonplace, see referents in a new perspective. Metaphors transform language and are not only rhetorical ornaments. It is understood that the figure of language has a genuine cognitive importance and is "untranslatable without remainder into literal language."(idem) The same happens to narratives and the act of narrating itself, where literature can take meaning to another level.

Take the allegorical and metaphorical implications surrounding character Lin, for example. She is a "khepri", a half-human, half-insect hybrid and her condition allows her to view multiple sides of the city at once through her scarab eyes. The mirrored effect provokes a compound kaleidoscopically visual cacophony, a million different sections of the whole: "Each visual fragment, each part, each shape, each shade of colour, differentiated from its surroundings in infinitesimal ways that told her about the state of the whole structure." (Miéville, 2000: 14- 15) Metaphorically, Lin's subjective visualizes a postmodern city, an allusion to the city of London, specifically. Great metropolises alienate their inhabitants; it is impossible to perceive all aspects of the city. Although a scarab has multiple views, Lin cannot integrate every perspective into a cohesive whole. The "infinitesimal differences" end up being only an assumption of the whole city. The narrator explains that the rest of the khepri seem to share such vision. The khepri are somewhat excluded, for the city of New Crobuzon pushes all their unwanted inhabitants toward the outskirts and the poorer regions of the city in a very subtle way. Discarded groups fail to notice they are being cut off from the city nucleus. Insectoids' subjective perspective, although multiple, does not allow them to actually perceive this. The inhabitants of New Crobuzon are constantly marginalized by each other and the city. Yet, the marginalized remain important because the people pushed to the margins are the protagonists. Lin is an artist, somewhat marginal figure in most metropolises. Involved in a lucrative contract to make a sculpture of a perverse drug dealer named Mr. Motley, she uses her own mucus excreted from behind her head carapace to accomplish the task. Partly insectoid, partly anthropoid, Lin is pursuing an identity. Through a more individualized art, she breaks away from her group in reach of such affirmation. Her relationship with protagonist Isaac is subversive. Even though New Crobuzon is built on hybridity, fraternization between species and other tribes is taboo. In fact, they have to hide their relationship from the less open-minded inhabitants.

Scientists are often seen as outcasts too, as we can observe in the protagonist Isaac Dan der Grimnebulin. Although humanoid, he is still considered subversive and misplaced due to his eccentricities. Isaac is described as a big, dark-skinned man and "dirigible", for he is generally 
absent-minded and aloft. Although a brilliant scientist, at home Isaac is a crude, vulgar man of mundane appetites and pleasures. This seems to be the reason he is chosen for his task, since he would willingly help a condemned criminal for the pure sake of a scientific experience.

In spite of his apparent rejection, it would be accurate to say that Isaac is from the dominant species of New Crobuzon. He is vaguely described as having a dark complexion: "Isaac stared uneasily and was thankful for his tight bulk and his skin the colour of smouldering wood." (Miéville, 2000 , p. 165) But whether or not he's black is irrelevant to the diegeses the narrative takes place in, he's still a member of the most privileged culture and gender in the city, an equivalent to the white male social position in our society. Functionally, xenians take up the role of human minorities; hence we can perceive the clash between social groups. When Isaac approaches the garuda ghetto, he does so with money and eloquent speeches, expecting to be listened to, expecting cooperation, and he is baffled when the leader rejects him. Isaac's attitude can be paralleled with dominant-majority individuals attempting to help the minority and getting angry when those efforts are antagonized. Miéville's strategy has a purpose, for if Isaac had helped Yagharek fly, it could be regarded as a dominant-majority group deciding a minority group issue, and the scientist would become an ultimate adjudicator of the Garuda laws and culture.

We can see somewhat of 'The White Man's Burden' here, popular concept in the late nineteenth century. Europeans often confronted the idea that capitalistic principles were the cause of imperialism, believing that European Imperialism was the natural way wealthier nations gained power. Those unable to follow would be overwhelmed. In Rudyard Kipling's poem, written to celebrate Queen Victoria's Diamond Jubilee, the poetic voice acts as a vaticinator, claiming that the glorious British Empire was at its end and that the United States of America would take over the burden of civilizing the world: "Take up the White Man's burden/Ye dare not stoop to less". Kipling did believe in the good the Empire was doing to its colonies. "White man's burden" was a very popular notion until the end of the nineteenth century. It was understood that it was the responsibility of white Europeans to bring "proper" European civilization to the nations of other ethnical groups. The main motif was that Europeans were correct in their beliefs and it was their duty to bring everyone in the world up as close to the European standards as possible. During European and American Imperialism, the white man's burden was often used as justification for expansion and annexation. Europeans were responsible for educating "uncivilized" or "primitive" peoples.

This also takes us to issues debated in Gayatri Chakravorty Spivak's Can the subaltern speak?. She claims that the ineptitude, or impairment, of westerners to speak about the other is derived from their inability to listen and understand the other without enforcing their Western consciousness and values. Mitigating this condition by giving the other a collective speech is bound to encounter problems, for the voice is not exactly genuine. Hence, the protagonist not taking such responsibility is preferred and works as a pertinent reflection of contemporary issues present in the city of London.

This brings us to another important character, Yagharek, the member of a flying species called garuda, whose wings have been cut off, and who asks Isaac to restore them. Isaac is challenged by the seemingly impossible nature of the commission, and gathers various flying animals to study in his lab - including a multicolored, unidentifiable caterpillar which later in the narrative becomes the reason of total chaos. Isaac is obsessed with his work and determined to understand everything about flight so he can restore it to those who have lost it and give it to those who want it.

Yagharek is half-bird half-man; although he is a foreigner, he almost immediately assimilates the cities vicissitudes. New Crobuzon will eventually swallow him, exerting tantalizing power: "How could we not see this approaching? What trick of topography is this, that lets the sprawling monster 
hide behind corners to leap out at the traveller? It is too late to flee." (Miéville, 2000, p. 02). Yagharek cannot experience the completeness of the city, nor can he bear the margins of society. He mingles in the city crowd in order to avoid the outskirts, for he considers triumph on the margins to be an inconsequential prize. In the beginning of Perdido Street Station, Yagharek doesn't belong in the city, but by the end of the novel he has seemed to have embraced it. His wings are the most significant part of his identity and he makes it a quest to recover them.

Since the nineteenth-century, when the term scientific marvelous was coined, we have witnessed the marvelous exploited in many senses. Most of the times, the supernatural and the uncanny are explained in a rational manner, but with laws contemporary science does not certify. Science fiction, when it does not slip into allegory, adheres to such apparatus. Nonetheless, as Ricoeur points out, the symbolical aspects and the discursive exercise with metaphors induce an allegorical approach without actually diverting these narratives from their objective. . In postclassical narratology, unnatural narratives are understood as mimetical exercises questioning verisimilitude in the level of the story and of discourse. When considered unnatural, narratives have a broader scope, sometimes even transcending this mimetical limitation. Fantastical and marvelous elements generally strike us as bizarre and question the standards that govern the real world around us. Although Fantasy worlds do also mirror the world we live in, they allow us the opportunity to confront the model when physically or logically impossible characters or scenes enhance the reader's imagination.

Narratologist Brian Richardson in his study Unnatural Narrative: Theory, History, and Practice (2015) distinguishes between the antimimetic, in his view, the more genuine unnatural, and the nonmimetic that appears more in fairy tales, beast fables and science fiction. He tends to consider that these genres are not unnatural in there essence, for the hesitation once pointed out by Tzvetan Todorov isn't exactly present. The worlds described have more of a marvelous touch.

Nonetheless, Pierre Mabillle reminds us that the meaning of the marvelous is beyond entertainment, beyond inquisitiveness, beyond all the emotions such narratives and legends induce. The meaning of the marvelous is also beyond the need to divert, to forget, or to achieve alluring or ghastly sensations. We can say that the real goal of the marvelous narrative is the total exploration of universal reality.

More allegorical and analytical aspects can be contemplated in the chart as follows:

\begin{tabular}{|c|c|}
\hline CHARACTERS & CHARACTERISTICS \\
\hline LIN & $\begin{array}{l}\text { The Scarab-headed god Khepri is depicted in Egyptian } \\
\text { mythology as a symbol of spontaneous creation, resurrection, } \\
\text { and transformation. It was said that he pushed the setting sun } \\
\text { along the sky. Scarabs were funerary talismans, placed on } \\
\text { the mummified corpses' rib cage, in order to guarantee a safe } \\
\text { passage of the soul to the netherworld. The first layer of the } \\
\text { scarab's wings, called elytra, is developed after a process of } \\
\text { sclerosis, crystallization. This process becomes an allegory of } \\
\text { the psychological development of the character, which seeks to } \\
\text { create layers of fossilized wings (represented by the sculpture) } \\
\text { to then fly or free herself (recognition). In the novel, Lin and the } \\
\text { khepri in general are going through transformation. }\end{array}$ \\
\hline
\end{tabular}




\begin{tabular}{|c|c|}
\hline YAGHAREK & $\begin{array}{l}\text { Occasionally the narrator, the garuda's desire is the quest of } \\
\text { the protagonist of the novel. Isaac sees the garuda as imposing } \\
\text { and powerful, but Yagharek gives another impression due to the } \\
\text { lack of wings. The bird of prey is a symbol of liberty, freedom, } \\
\text { and victory mostly because it is pictured with its appendage. In } \\
\text { Egyptian mythology the sun god is represented in a zoomorphic } \\
\text { form having a falcon's head, hence the grandeur of the bird of } \\
\text { prey. Yagharek is after respect and, mainly, identity. }\end{array}$ \\
\hline ISAAC DAN DER GRIMNEBULIN & $\begin{array}{l}\text { The rogue scientist idea is much exploited in sci-fi. Isaac leaves } \\
\text { academia also in search of freedom. Generally, scientists abide } \\
\text { by a strict set of principles that ensure the development of their } \\
\text { projects, in Isaac's case, the proof Unified Energy Theory relates } \\
\text { to organic and mechanical forms. Science is the sole purpose } \\
\text { here, what it can accomplish and what it represents in society. } \\
\text { Yagharek is viewed as a deity although the narrator reminds } \\
\text { us that: 'Isaac worshipped no gods. He did not believe in the } \\
\text { omniscience and omnipotence claimed for a few, or even the } \\
\text { existence of many. Certainly there were creatures and essences } \\
\text { that inhabited different aspects of existence and certainly some } \\
\text { of them were powerful, in human terms. But worshipping them } \\
\text { seemed to him rather a craven activity.' (p. 60) }\end{array}$ \\
\hline THE REMADE & $\begin{array}{l}\text { The major kind of castigation in New Crobuzon is to be "remade". } \\
\text { Punished citizens are artificially altered, generally into a mechanic } \\
\text { submissive creature. The dystopia in the narrative appears when } \\
\text { we gradually accompany the considerable number of the remade } \\
\text { that skirt around the city. Vassals are modeled to fit the will of } \\
\text { the powerful and New Crobuzon embraces this pathology. Unlike } \\
\text { the sentient, the remade are different, but molded to a difference } \\
\text { the city will accept. They are almost symbiotic with the engines } \\
\text { and the vapors emitted by exhaust pipes, part of the transfiguring } \\
\text { scenario. }\end{array}$ \\
\hline THE CACTAE & $\begin{array}{l}\text { One of the most fascinating species of the narrative, the cactae call } \\
\text { attention because of their representation. The cactus is generally } \\
\text { associated with endurance and the ability to adapt to situations } \\
\text { and environments, a symbol of resistance, so to speak. In an } \\
\text { inhospitable city as New Crobuzon, one would understand why } \\
\text { an entire gender would resemble the appearance and physiology } \\
\text { of a cactus in order to resist the intermittent changes provoked } \\
\text { by the progression of the urbe. They survive because they can } \\
\text { mingle and accustom. }\end{array}$ \\
\hline
\end{tabular}




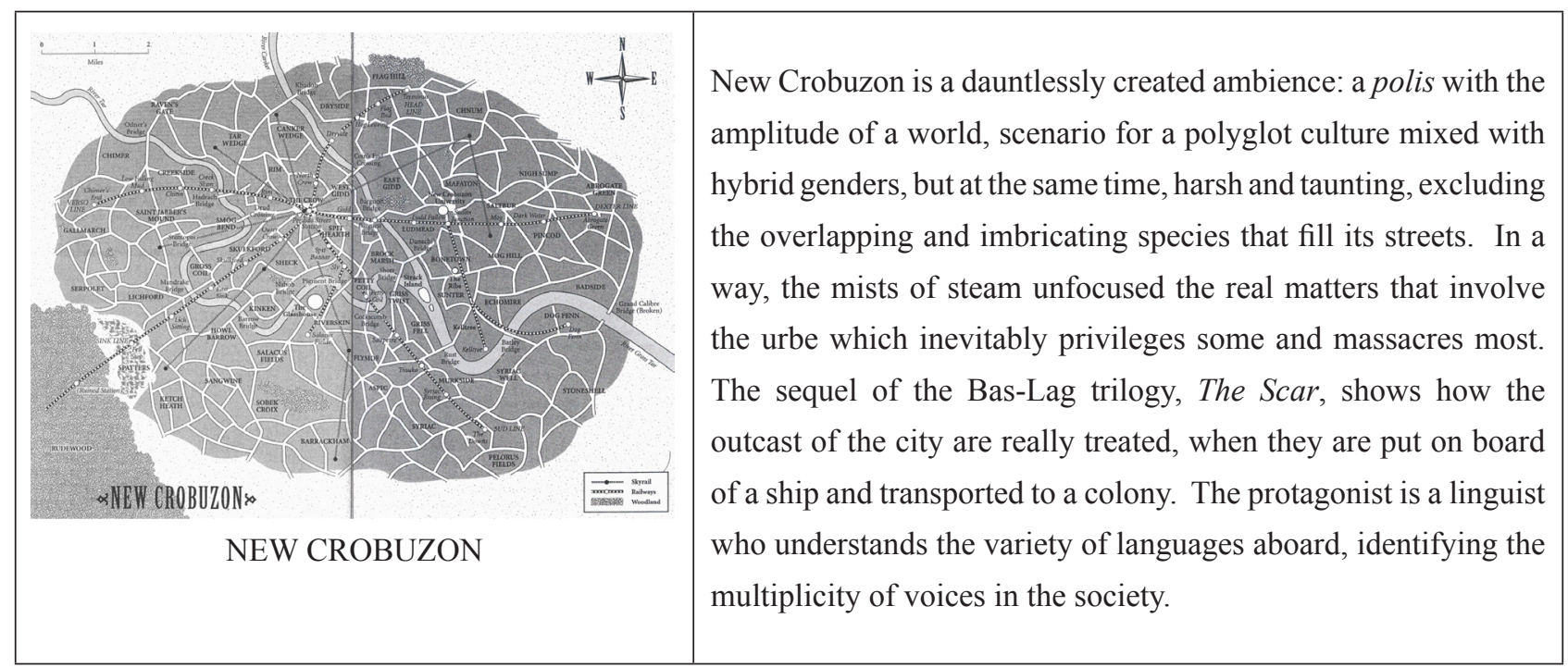

Maurice Renard reminded us when the scientific-marvelous was still an incipient genre:

\begin{abstract}
The influence of the scientific-marvelous novel on such a concept of progress is considerable. Being forcefully convincing by its very rationality, it brutally unveils for us all that the unknown and the uncertain perhaps hold in store for us: all those wonderful or horrible things that might emerge from the depths of the unexplainable, all that science is able to discover by extending itself beyond those many inventions which seem to mark its end, all those unforeseen yet possible byproducts of such inventions, and all those new sciences which might develop to study such unsuspected phenomena.... It portrays our daily, humdrum lives shaken up by various cataclysms of the most natural yet unexpected sort. It reveals to us, in a new and startling light, the instability of everyday occurrences and the omnipresent threat of the possible. It causes us to feel the uncomfortable queasiness of doubt and, with frightening intensity, the horror of the unknown. It opens up for us an immeasurable space outside of our immediate sense of well-being; it removes from our ideas about science all notions of domestic applicability or sentimental anthropomorphism. It fragments our habitual lifestyle and transports us to other points of view outside of ourselves. (RENARD, 1994, p. 400)
\end{abstract}

Tzvetan Todorov remarks that in the case of the marvelous, supernatural elements provoke no particular reaction either in the characters or in the implicit reader. It is not an attitude toward the events described which characterizes the marvelous, but the very nature of events. Perdido Street Station's dense prose intensifies the marvelous by remitting to the poetic resource of visual imagery. Its impacting ziggurats in the high style scenario, aligned with the grotesque, give us an ambience that rejects any escapist proposition. The rich texture seen in the narrative metaphors help shape Miéville's fictional city and it is no coincidence that the novel is named after a location.

Wisely plotted, the story of Isaac Dan der Grimnebulin's ideal of working on a United Theory that would blend alchemy, magic, and science into one concept is obliterated after a bizarre release of moth-like creatures that feed on dreams. After tremendous ordeals to make his wrongs right, the scientist has to resort to the Weaver, a sort of a delirious computer that connects all information in New Crobuzon. The narrative resource of the deus ex machina seems to apply, and the mega-spider creature is the divine intervention.

A very suggestive allegory... In the primeval stage of writing, copyists wrote their texts on cloths, hence the Latin word textere to describe something registered on texture. From such lexicon derived the radical form text-, present in various Western languages, usually describing the act of writing itself. The fact that the product was literally written on a texture, and that this texture was a confection, contributed to the close relation between discourse and weaving. The importance of the ruse of the web is evident. To weave and to narrate have the same implication. The act of weaving refers to the ability to fabulate. The ability to master threads is equivalent to that of mastering discourse. Ovid's Metamorphoses contains the story of the Lydian Arachne. Having claimed that she was a better weaver than Athena, the mortal was punished, although her craftsmanship was recognized, and she 
received the redemption of being metamorphosed into a spider, a creature that will always weave. This myth illustrates the use of weaving as an expression of feminine intellectual performance and how the power of the gods cannot be contested.

Texture and plotting are the solutions to Miéville's narrative. Readers seeking for character redemption or a traditional denouement will be disappointed. As a matter of fact, the narrative never loses itself in vast and monotonous descriptions; the text is meticulously woven, in order to give New Crobuzon an adequate allegorical representation of a referent, in this case, London, which is also drowned in miasmas of intolerance and exclusion, "maked-up" by the standards of a cosmopolitan megalopolis.

New Crobuzon reveals that fantasy and politics can't be unravelled. It is a metropolis of conflicting cultures, a pungent London. For the other Bas-Lag cities, it's an imperial power, pursuing to extend itself, using the embrace of a mother, but at the same time, condemning everything with an intricately woven spider web thread.

\section{Works Cited}

BIEDERMANN, Hans. Dictionary of Symbolism: Cultural Icons and the Meanings Behind Them. Trans. James Hulbert. New York: Facts on File, 1992

CHEVALIER, Jean and Alain Gheerbrant. The Penguin Dictionary of Symbols. Trans. John Buchanan-Brown. London: Penguin, 1996

DAUENHAUER, Bernard, PELLAUER, David. "Paul Ricoeur", The Stanford Encyclopedia of Philosophy. Edward N. Zalta ed., 2011

KIPLING, Rudyard. 1990. Something of Myself, and Other Autobiographical Writings. ed. Thomas Pinney. Cambridge: Cambridge UP, 1990

LAUSBERG, H. Handbook of Literary Rhetoric: A Foundation for Literary Study Leiden: Brill, 1998

MABILLE, Pierre. Le merveilleux. Saint Clément de rivière : Fata Morgana, 1992

MIÉVILLE, China. Iron Council. London: Del Rey, 2004

MIÉVILLE, China. Perdido Street Station. London: Del Rey, 2000

MIÉVILLE, China. The Scar. London: Del Rey, 2002

RELPH, Edward. Place and Placelessness. Chicago: Pion Ltda, 1976

RENARD, Maurice. 1994. On the Scientific-Marvellous Novel. Trans. Arthur B. Evans

Science Fiction Studies. (397 405http://scholarship.depauw.edu/mlang_facpubs/21/)

RICHARDSON, Brian. Unnatural Narrative: Theory, History, and Practice. Columbus: Ohio State UP, 2015

RICOEUR, Paul. The Rule of Metaphor. Multidisciplinary Studies of the Creation of Meaning in Language. Transaltion by Robert Czerny. Toronto: University of Toronto Press, 2008

SEAMON, David. Key Texts of Human Geography. Los Angeles: Sage, 2008

SPIVAK, Gayatri Chakravorty. A Critique of Postcolonial Reason: toward a history of the vanishing present. Cambridge: Harvard University Press, 1999

TODOROV, Tvetan. The Fantastic: A Structural Approach to Literary Genre. 3rd ed. Ithaca: Cornell UP, 1975 
